\title{
Köpek Dişi Ya Da “Mülklerin En Tehlikelisi” Olarak Dil ${ }^{1}$
}

\author{
Güven Özdoyran*
}

\begin{abstract}
Özet
Wittgenstein için felsefenin amacı şişenin içinde hapsolmuş sineğge dışarı çımanın yolunu göstermektir. Wittgenstein açısından metafizik ile sineğin 'yanlış-bilinci' aynı türdendir: Şişenin içindeki sinek, sanki şişenin dişından bakıyormuş gibi 'şişe' (dünya) hakkında yanlış bir biçimde konuşmaktadır. İmgeler üretme gücüne sahip olan sinema, 'beden-bağımlı-konum olarak göz'den farklı olarak, bize 'şişe'yi dışarıdan gösterme kabiliyetine sahiptir. Yorgos Lanthimos'un Köpek Dişi (Kynodontas) filmi tam da bize içinde yaşadığımı şişeye bir meta-bakış ile bakmamızı să̆layan bir evren kurar. Genel kanının aksine Köpek Dişi filmi 'normal' olandan 'sapma' durumuna, bir 'patoloji'ye işaret etmez. Tam tersine, film, içinde yaşadığımız ve dil yoluyla inşa edilen toplumsallı̆̆ın 'gerçek' ve 'normal' olarak algılanmasına yol açan kodları ifşa eder. Aslında, filmde anlatılan hepimizin hikayesidir. Bu bağlamda, Lacanyen psikanaliz ve Lacan'in dil'i ve toplumsallığı kavrama biç̧mi Köpek Dişi filmini analiz ederken izleyiciye/ okuyucuya güçlü bir enstrüman sağlar. Lacanyen strateji ile konuşacak olursak film bize hakikatin ne olduğunu anlatmaz, çünkü hakikat anlatılamayandır. Köpek Dişi bize hakikatin ne olmadığını 'gösterir'. Bu bildirinin temel iddiası, Lacan'ın 'Simgesel Düzen'i ile Lanthimos'un filminde kurulan evrenin kesiştiği fikridir. Böylelikle, bu çalışmada Lanthimos'un Köpek Dişi filmi Lacanyen paradigma merkeze alınarak çözümlenecek ve 'dil' denilen apparatusun gerçekliğimizi inşa etme sürecindeki merkezi rolü tartışlacaktır.
\end{abstract}

Anahtar Kelimeler: Lanthimos, Köpek Dişi, Lacan, Dil, Psikanaliz, Simgesel Düzen

ORCID ID : 0000-0002-8377-513X

E-mail : guvenozdoyran@arel.edu.tr

DOI: $10.31122 /$ sinefilozofi.517490

Geliş Tarihi - Recieved: 24.01.2019

Kabul Tarihi - Accepted: 01.03.2019 


\title{
Dogtooth or the Language as "the Most Dangerous of Goods"1
}

\author{
Güven Özdoyran*
}

\begin{abstract}
The aim of philosophy, for Wittgenstein, is to show the way out to the fly trapped in the bottle. According to him, metaphysics and the fly's "false-consciousness" are of the same kind. The fly inside the bottle speaks falsely about "the bottle" (the world) as if it were looking from the outside of the bottle. Cinema with the power to produce images, unlike the eye as a body-dependent position, has the ability to show the bottle from outside. Yorgos Lanthimos' Dogtooth (Kynodontas) creates a world that allows us to look at the bottle we live in with a meta-view. Contrary to common belief, Dogtooth is not the story of an abnormal, pathological family. In fact, it reveals the codes that cover the abnormalities in the society, constructed through the language, we live in. It is, indeed, the story of all of us which is told in the film. In this context, Lacanian psychoanalysis and Lacan's way of understanding the language and society provide audiences with a powerful tool for analyzing the film. With the Lacanian strategy, the film does not tell us what the real is, because the real is unexplainable. It shows us what the real is not. The main claim of this paper is the idea that Lacan's Symbolic Order and the world established in Dogtooth extremely intersect. In this study, Lanthimos' film will be analyzed by putting the Lacanian paradigm at the center and the central role of the language in the process of constructing our reality will be discussed.
\end{abstract}

Keywords: Lanthimos, Dogtooth, Lacan, Language, Psychoanalysis, Symbolic Order.

ORCID ID : 0000-0002-8377-513X

E-mail : guvenozdoyran@arel.edu.tr

DOI: 10.31122 / sinefilozofi.517490

Recieved - Geliş Tarihi: 24.01.2019

Accepted - Kabul Tarihi: 01.03.2019 


\section{Giriș}

Tüfek (isim): Güzel, beyaz bir kuş türü

Köpek Dişi

"Her şey gösterenin yapısından kaynaklanır."

Lacan, Seminer XI

Psikanaliz, sinema söz konusu olduğunda iki yönlü işlev görür: Birinci durumda, sinematik aygitın kendisine odaklanan "aygit kuramı", sinema deneyiminin bizatihi kendisini, izleyiciyi "sinema perdesine bağlayan psişik süreçleri" (Arslan, 2009: 6) merkezine alır: "Sinema deneyiminden neden keyif alırız?" sorusunun cevabını vermeye çalışır. İkinci durumda ise, film içeriklerinin analizinde bir araç olarak kullanılır: Psikanalitik film çözümlemesi Kynodontas (Köpek Dişi, Yorgos Lanthimos, 2009) filmi ise önümüze üçüncü ve tekil (kendine münhasır) bir alan açar. Film izleyiciye, Lacan'ın "simgesel düzen" adını verdiği dilsel-kültürel mekanizmanın hem anlamı tayin eden hem de bireyleri özne olarak tahkim eden düzeneğini dolaysız bir biçimde gösterir. Bu makalenin temel iddialarından birisi de, filmdeki bu mekanizma ile içinde yaşadığımız dünyadaki mekanizmanın örtüştüğüne yönelik olacaktır. Lacan, Edgar Ellen Poe'nun “Çalınan Mektup” hikayesini analiz ettiği seminerinde, özneyi kuran simgesel düzenin bu "hakikatini", gerçek hayatta değil ama bir kurgu, yani öykü, (bizim örneğimizde ise Köpek Dişi filmi) üzerinden göstermenin iyi bir seçenek olduğunu söyler (Lacan, 2005a: 34). Çünkü bir kurgunun "kendi varoluşunu olanaklı kılan” şey, simgesel düzen'in kendisinin de kurguya yakın bir yerde konumlanmasıdır.

Başlamadan önce vurgulamamız gereken önemli bir husus olarak, bu makale boyunca Köpek Dişi filmi Lacan'ın teorisini açıklamak için araçsallaştırılmayacaktır; tam tersine, Köpek Dişi filminin ne anlattığını doğru bir biçimde kavrayabilmek için Lacan'ın argümanları birer enstrüman işlevi görecektir.

Köpek Dişi, şehir dışında, etrafı çitlerle çevrili müstakil bir evde yaşayan anne, baba ve yirmili yaşların başında olan iki kız kardeş ve tek erkek kardeşten oluşan bir ailenin hikayesini anlatır. Şehir merkezinden uzakta dünyadan tümüyle yalıtılmış bir hayat yaşayan bu ailede dış dünya ile bağlantısı olan tek kişi babadır. Baba, işyerine gitmek için evden çıkar ve ailenin ihtiyaçlarını karşılar. Bunun dışında, evin etrafını saran çitlerden dışarı hiç kimse çıkamaz. Evdeki çocukların dış dünya ile bütün bağlantıları koparılmıştır. Dışarıdan evin içerisine girmesine izin verilen tek kişi babanın çalıştı̆̆ fabrikada güvenlik görevlisi olan Christina' dır (Filmde diğer hiçbir karakterin ismi yoktur). Çocukların ise dışarı çıkabilmek için köpek dişlerinin düşmesi gerekmektedir.

Köpek Dişi filmine yönelik, her filmde olduğu gibi, birden çok anlama/yorumlama biçimi olduğu söylenmelidir. Bu anlama/görme biçimlerinden biri açısından Köpek Dişi, “otoriter rejimlerin" açık bir metaforudur. Filmin, Yunanistan'da 1960'ların sonuna doğru gerçekleşen askeri darbe sonrası kurulan cunta yönetiminin/otoriter rejimin bir metaforu olduğu yorumu özellikle filmin kendi coğrafyasında (Yunanistan' da) oldukça yoğun gündeme gelmiştir. Ancak Lanthimos ilk ağızdan, filmin bu türden okumasının yanlış olduğunu verdiği bir röportajda belirtir. 
Bir başka yoruma göre ise film, "normalin dışında", "sapkın-patolojik" bir ailenin hikayesini anlatır. Ancak, dikkatle bakılırsa, filmin ana odağının "ailenin psikolojik durumu" değil ailenin/babanın kurduğu 'yapı' olduğu görülecektir (Tyrer, 2017: 107). Filmde ailenin geçmişine dair sahne olmadığı gibi, buna işaret eden bir ima ya da gönderme de bulunmaz. Ailenin, ebeveynlerin psikolojisine yönelik hiçbir iz bulamayı. Lanthimos bu noktaları kasıtlı olarak izleyiciden kaçırıyor da değildir, film bu noktalara karşı tümüyle kayıtsızdır. Bu makalenin temel önermesini şu şekilde özetleyebiliriz: Köpek Dişi, "normal" olandan "sapma" durumuna, bir 'patoloji'ye işaret etmez, tam tersine, film, içinde yaşadığımız ve "dil" dolayımı ile inşa edilen/üretilen toplumsallığın 'gerçek' ve 'normal' olarak algılanmasına yol açan kodları aşırı-göstererek itibarsızlaştırır.

Bir başka ifade ile, filmde anlatılan ailenin 'yapısı' ile Lacan'ın çerçevesini çizdiği biçimiyle içinde yaşadığımız toplumsallığın 'yapısı' radikal bir biçimde örtüşmektedir. Film, Lacan'ın temel itirazlarını, örneğin "cinsel ilişki diye bir şey yoktur" ya da "arzu her zaman Öteki'nin arzusudur" önermelerini, Althusser'in ideoloji bağlamında dolaşıma soktuğu, Zizek'in ise 'simgesel düzen' bağlamına oturttuğu "öznenin çağırılışı" kavramını, ürettiği imgeler yoluyla izleyiciye dolaysız ve son derece kuvvetli bir biçimde gösterir. Dahası, filmde belki de ilk defa bu kadar doğrudan ‘Büyük Öteki'ni, Büyük Öteki'nin eril kimliğini ve özneleri dil aracılığı ile nasıl ürettiğini görürüz.

Buna imkan sağlayan temel faktör ise filmdeki ailenin dişarıya kapalılığıdır. Köpek Dişi' nde izleyiciyi zorlayan noktalardan bir tanesi, filmin kurduğu kapalı evrende, merkezinde evin yer aldığ 1 "içerisi-dışarısı" antagonist karşıtlığın bizatihi kendisidir. Film boyunca, aile ile aramıza koyduğumuz grotesk mesafenin imkanı olan 'evin içerisi-dışarısı' karşıtlı̆ııın asıl dayanağı, aynı zamanda filmde evin 'dışarısı' ile sinemadan çıktığımızda içine karıştığımız 'dışarısı'nın kesiştiğine dair kanaatimizdir. Çok benzer şekilde, aynı kanaati, Truman Show filminde yer alan Truman'ın 'içinde' yaşadığı stüdyo ile stüdyonun 'dışarısı' ayrımında da taşırız. Dolayısıyla, bu yazı boyunca da 'dışarısı' dediğimizde iki alanı kastediyoruz: Hem filmdeki 'evin' dışarısı ve bunun kategorik eşiti kabul edilen toplumsal olarak var olduğumuz 'dışarısı', bir başka ifade ile, dilin/simgesel' in kurduğu ve bizim tarafımızdan "dünya olarak okunan şey" (Lacan, 2014: 297) ya da Lacanyen terminoloji ile, 'gerçeklik'. Buradaki temel mesele hangi aile yapısının, yani 'evin dışındaki ailelerin mi yoksa evin içindeki ailenin mi' veya filmin dışındaki 'içinde yaşadığımız yapının mı yoksa filmdeki ailenin yapısının mı' doğru veya yanlış olduğunu belirleyecek 'gerçek', 'nesnel' ve 'doğal' bir referanstan/zeminden yoksun olmamızdır. Bu anlamda, bu makalenin üzerine yapılandırıldığı iddia, 'evin içerisi ve dışarısı' hattını belirleyen ontolojik bir sınırın olmadığı, sanıldığı gibi dışarısının 'özsel' olarak doğru, içerisinin ise kategorik olarak yanlış olduğu inancının sorunlu bir yaklaşım olduğu üzerinedir. Buna mukabil, bu ayrım aslında evin içindeki 'sınırlı simgesel düzen' (simgesel düzen kavramını merkezinde dilin olduğu kültürel düzen olarak okuyabiliriz) ile evin dışındaki daha geniş mutabakata dayalı 'simgesel düzen' arasındaki farktan ibarettir. Çünkü, yine Lacan açısından, bu yapıların eşzamanlı olarak hem var oldukları hem de kendilerini tanımladıkları/konumlandırdıkları zemin olarak 'simgesel düzen', doğal, nesnel ve Gerçek değildir. Bir başka ifade ile, 'evin içerisi ve dışarısı' aslında 'dilsel bir ayrımdır', ya da 'dilin' işlevinin kaçınılmaz sonucu olarak ortaya çıkmış bir karşıtlıktır. Derrida perspektifinden söyleyecek olursak, bu ayırımı yapmamıza olanak tanıyan a priori, deneyime önsel ve onun koşulu olan, dolayısıyla kendiyle özdeş bir zemin/köken yoktur. Bir başka ifade ile, köken her 
zaman için homojen bir tekilliği değil ama heterojen çoğulluğu imlemektedir (Derrida, 1991: 105-109). Bu anlamıyla, üzerine şüphe duyulamayacak derecede kesin ve açık bir Kartezyen başlangıç noktası/zemin yoktur. Yapılardan birinin yanlış olduğuna hükmetmek için zorunlu olan işlemin, yani iki yapıyı 'karşılaştırma' işleminin, böylesi nesnel bir zeminden yoksun oluşu, her türden 'kıyaslamanın' (örneğin bir kültürü diğeri ile kıyaslamanın ve bu işlemin zorunlu sonucu olarak bir hiyerarşi kurup birini diğerinin üzerine konumlandırmanın) imkansızlığını da beraberinde getirir..$^{*}$ Paradoksal bir biçimde, bize 'bu aile gibi olmadığımız' fantazisini kurduran ve böylelikle bizi rahatlatan mekanizma, yani bize kaçış imkanı tanıyan düzenek ile buradaki çıkmazın nedeni olan mekanizma aslında aynıdır: Simgesel Düzen. ${ }^{{ }^{* *}}$

Bu makalenin önerisi, filmin meselesini yorumlamak için yorumlanan nesneyi (Köpek Dişi filmini) kendi başına/özgönderimsel olarak değil, ama diğer filmlerle açık ya da kapalı ilişkisine bakarak ele alınmasının gerekliliği üzerine olacaktır. Derrida'nın yapı-söküm stratejisinin kendisi hali hazırda bir 'yeniden-okuma', bir 'taktiksel tersine çevirme' olmasına rağmen, burada yapı-söküm sürecinin istikametini tersine çevirerek (söküme uğratılan referans metinden, söküm sonucu oluşturulan metne doğru değil; söküm sonucu ortaya çıkan metinden -ki buradaki örneğimiz Köpek Dişi filmi- söküme uğratılan metin ya da metinlere doğru) başlamak, eğer böyle bir müdahale meşru ise, filmin meselesini kavramak için isabetli bir hamle olacaktır. Böylesi bir tersine çevirmenin meşru olduğu Derrida'nın stratejisine bakıldığında görülebilir. Örneğin, Derrida'nın yapı-söküme uğrattığı Platon'un Phaedrus (Pharmakon) metninden Derrida'nın “Plato's Pharmacy" (Derrida, 2017: 61-65) metnine gidiş, ayn zamanda "Plato's Pharmacy" metninde Pharmakon'a doğru gidişe de imkan tanır. ${ }^{3}$ Bir başka örnek olarak, J. M. Coetzee, Daniel Defoe'nun Robinson Crusoe metnini Post-Kolonyalist perspektiften yeniden okuyarak yapı-söküme uğratır ve ortaya Foe ${ }^{4}$ romanı çıar. Defoe'nun metninde itibar görmeyen, kenarda bırakılan temalar merkeze doğru çekilir (örneğin, Foe'da "Cuma" artık metnin merkezindedir, ilk metinde hiç olmayan "kadın", bu metinde hikayenin hem anlatıcısı hem de ana karakterlerinden biridir, yine ilk metinde Robinson, Cuma'nın kültürüne veya diline yönelik hiçbir ilgi duymaz, hatta tepeden bakar, Cuma'ya kendi anadili olan İngilizce'yi öğretir, protestanlaştırır ve yeni bir Cuma öznesi üretir) ve böylelikle metnin ve genel olarak kültür dediğimiz yapının, kolonyalist/sömürgeci tonu açı̆̆a çıkarılır. Yine çok benzer şekilde, Coetzee'nin Foe metninden hareketle Defoe'nun Robinson Crusoe metnine regresif bir hareket yapilabilir.

Lanthimos, bu bağlamda, oldukça sıradan bir hikayeyi 'yeniden' okumayı önerir: Ana akım aile filmlerini ve bu filmlerdeki 'kutsal aile temasını'. Yapı-söküm bağlamında Köpek Dişi filmini şu şekilde özetlemek sadece provokatif değil aynı zamanda kaçınılmazdır da: Film aslında içten, samimi bir aile hikayesi anlatır. Birbirine sıkı sıkıya bağlı, mutlu bir hayat süren ailenin düzeni, dışarıdan gelen bir 'yabancı' nın kötücül müdahaleleri sonucu bozulur, çatışmalar baş gösterir, 'ailenin istikrarlı mutluluğu' 'ailenin çözülüşüne' doğru evrilir ve

1 'Özcülük', 'özcülüğün stratejik kullanımı' ve kültür bağlamında yapı-sökümcü nominalizm tartışmaları için: Spivak, "Eleştirel Bakış", der. Peter Osbourne", s. 200-217

2 Lacan, "düşüncenin kendini dayandırdığı dünyayı (Umwelt)", yani 'gerçeklik' düzlemini, "fantazinin mahali" olarak da görür (Lacan, 1990: 44).

3 'Pharmakon', Yunanca hem ilaç/tedavi, hem de zehir anlamına gelir. Platon kendi metnini kelimenin ilaç/ tedavi anlamı üzerinden kurarken, Derrida ise bu metni kelimenin 'zehir' anlamını öne çıkartarak söküme uğratır ve yeniden yapilandirrr.

4 Foe, 'yabanc1, düşman' anlamına gelir. Türkçeye de Düşman adıyla çevrilmiştir. 
fedakâr baba ailenin içine düştüğü bu sıkıntıları aşması ve bozulan aile birliğini yeniden tesisi için bir ölüm-kalım mücadelesine girer. Burada, Foe ile Köpek Dişi arasındaki benzerliği tekrar fark ederiz. Sıkı bir dostluk hikayesi olarak okunan Defoe'nun Robinson Crusoe'sunun aslında Robinson'un Cuma'ya uyguladığı tahakkümün hikayesi ya da Cuma'nın Robinson tarafından özne olarak tahkim edilmesinin hikayesi olarak 'yeniden okunması' gibi, Köpek Dişi de, aile hikayelerini yeniden okuyarak bu hikayelerde gizlenen tahakküm ilişkilerini açığa çıkartır. Ana akım filmlerin merkezindeki ailelerin de, adadaki Cuma'nın da aslında 'ne anlama geldikleri/neyi temsil ettikleri', hikayelerindeki kendi temsillerinin merkezinde değil, kenarlarında göz ucuyla belirir: Dil dolayımı ile üretilmiş, mutlu köle özneler. Dolayısıyla Köpek Dişi, bir temsilin nasıl temsil edildiğini, onun 'neden' temsil edildiği üzerinden (yani, onu yeniden okuyarak, aslında neyi temsil ettiği üzerinden) anlatır. Tam da bu yüzden film kendini doğrudan dildeki anlamın istikrarsızlığı ve temsilin krizi üzerinden yapılandırır.

Yunan Yeni Dalga Sinemasının en etkili yönetmenlerinden biri olan Yorgos Lanthimos, Köpek Dişi ile, Marx'in Hegel'in sistemine yönelik ifadesini ödünç alarak söyleyecek olursak, tepe taklak duran bu aile hikayelerini/filmlerini ters yüz ederek ayakları üzerine oturtur. Köpek Dişi klasik aile hikayelerini, bu hikayelerde izleyiciden kasten ya da gayriihtiyari kaçırılan, kenarda bırakılan aporia'ları (ya da Kuhn'un perspektifinden anomali'lileri) merkeze taşıyarak yeniden kurar ve böylelikle yapı-söküme uğratır. Bu türden 'ters yüz' etmenin kaçınılmaz sonucu olarak, film "aile kurumuna" yapılmış en açı ve doğrudan saldırı olarak karşımıza çıkar. O halde, baştaki önermemize geri dönüp söyleyecek olursak, tarafları bir uçta mutlu ve normal aile hikayeleri, diğer uçta ise Köpek Dişi'nde anlatılan anormal bir aile hikayesi olarak konumlandırmak hata olacaktır. Birbirine temas etmeyen, birbirine karşıt iki farklı aile hikayesi söz konusu değildir. Tam tersi, burada anlatılan, anlatıcının stratejisine ve gözlemcinin konumuna göre farklılaşan aynı hikayenin iki ayrı veçhesidir.

Yukarıda sözü edilen okuma biçimiyle ilintili olarak bir diğer önermemiz, filmin metaforik bir dil kullanmadığı, 'metafor'lar üzerinden ilerlemediğine, filmde anlatılan ailenin ve yapının bir metafor olmadığına yöneliktir. Filmdeki baba bir otoriter rejimi 'temsil etmez', onun göstereni değildir. Film gerçekliği metaforik olarak, simge/semboller yoluyla anlatmaz, tam tersine doğrudan, dolaysız bir biçimde gösterir. Bu anlamıla Köpek Dişi, paternal anlamlandırma rejimlerinin söylemsel olarak ürettiği gerçekliğin bir aşırı-gösterimidir.

Aile, Lanthimos sinemasının başat temasıdır. The Lobster, Köpek Dişi, Kutsal Geyiğin Ölümü, aileyi merkeze alan hikayeler anlatır ya da daha doğru bir ifade ile aile kurumunu sorunsallaştırır. Lanthimos sinemasını Haneke sinemasına yaklaştıran sebeplerden biri de bu tematik ortaklıktır.

Lanthimos'un böylesi bir "aile" saplantısı tesadüf müdür? Bu soruya tarihsel bağlamda başka bir soruyla cevap verilebilir: Marx'ın Kutsal Aile metni ile Bauer kardeşler üzerinden aile kurumunu da eleştiri nesnesine dönüştürmesi, Manifesto' da ebeveynlerin çocukları üzerinde kurdukları tahakküme güçlü bir vurgu yapması ve itirazını yükseltmesi (Marx, 2014: 60) ve Marx'1 yapisalc1 perspektiften yeniden okuyan Althusser'in (2006: 63-64) aile kurumunu 'Devletin İdeolojik Aygitları' arasında en kadim olanlarından biri olarak mahkûm etmesi ${ }^{5^{*}}$ tesadüf müdür? Benzer şekilde, Foucault için de 'aile', 'disipline edici' kurumların başında

5 Althusser tarihsel olarak değişen devletin ideolojik aygıtlarını sınıflandırırken, kurduğu ikiliklere her zaman aile'yi dahil eder: Toprak aristokrasisinde 'kilise-aile aygıtı', sanayi burjuvazisinde 'okul-aile aygıtı'na dönüşür (Althusser, 2006: 73). 
gelir (Foucault, 2007: 40-44). Foucault'nun analizine göre, 'aile' iki ayrı iktidar teknolojisinin de, 'disipline edici iktidar' ve 'biyopolitik iktidar', odağındadır.

Lacan açısından da 'aile'nin bu derece merkezi bir rol üstlenmiş olması yine 'dil' üzerinden gerekçelendirilir. Ona göre, aile'nin insan topluluklarının temelinde yer almasının nedeni, ailenin dilin kendi egemenliğini kurduğu ilk krallık olmasından ileri gelir (Roudinesco,2012: 36). Halihazırda psikanaliz' in temel kavramlarından biri olan ve kültür dünyasına girişin eşiği olarak kabul edilen 'oedipus', doğrudan 'aile' nin hikayesidir.

'Dil' ve 'dilin kullanım biçimi' hem filmin merkezindedir hem de filmin en tartışmalı içeriklerinden bir tanesidir. Filmin açılış sekansı yakın plan çekim ile başlar. Bu sahnede bir el kaset çalara bir kaset yerleştirir. Üç kardeş teypte çalan kasetle 'eğitilirler'. Kasette, 'günün kelimeleri' öğretilmektedir:

“Günün yeni kelimelerini dikkatle dinleyiniz. Deniz: Ahşap kolluklu deri koltuk. Otoban: Çok güçlü bir rüzgar türü. Seyahat: Zemin kaplamada kullanılan madde. Tüfek: güzel beyaz bir kuş türü."

Devamında bu kelimeler cümle içinde örneklendirilerek doğru kullanımları gösterilir. “Deniz: Ayakta kalmayın, 'denize' oturun da konuşalım”. Bir diğger sahnede, yemek masasında yemek yenilirken 'tuzluk' işaret edilerek "telefonu uzatır mısın?" denilir. 'Telefon' kelimesi, 'tuzluk' nesnesini işaret etmektedir. Bir diğer örnekte, Christina' nın dışarıdan içeriye sızdırdığı 'zombie' kelimesinin ne anlama geldiğini soran erkek kardeşe cevap olarak anne 'küçük sarı bir çiçeğin adı' olduğunu söyler. Burada kritik olan, yeniden üretilen bu dil ile dildeki 'gösteren' ve 'gösterilen' arasındaki ilişkinin keyfiliğidir. Bir başka ifade ile, babanın, nesnelerin ve kelimelerin 'anlamı' ile ilgili yeni bir 'göstergeler sistemi' kurmasıdır. Böylelikle hem nesnelerin anlamı hem de nesnelerin düzeni, babanın patriarkik anlam rejimine göre yeniden düzenlenir. İzleyiciyi şaşırtan, 'nesnelerin bu denli keyfi yeniden-düzenlenişidir'. Burada bizi zorlayan fikir şudur: Babanın bu keyfi yeniden düzenleyişinin 'yanlış', bizim dildeki konumlandırmalarımızın ve anlamlandırmalarımızın 'doğru' olduğunu nasıl gösterebiliriz? Bir başka ifade ile, 'deniz' kelimesinin diş dünyadaki 'deniz' nesnesini imlemesi, 'o' anlama gelmesi keyfi değil ama zorunlu mudur? Zorunlu olmadığını Saussure göstermiştir. Dilde anlam, 'gösteren' ile 'gösterilen' arasındaki zorunlu olmayan, keyfi ilişkiselliğe, öznelerarası 'uzlaşıma' dayanır. Aynı şekilde, filmde de anne-babanın uzlaştığı anlam, çocuklar tarafından 'nesnel gerçek' olarak kabul edilir. Çocuklar yeni bir kelime öğrenirken onun anlamını dış dünyadaki nesneye referans ile öğrenmezler. Daha önceden babanın öğretmiş olduğu sözcüklerle ilişkilendirerek yeni kelimenin anlamını kavrarlar. Burada, 'tahakküm' kendisini yeniden gösterir: Çocuklar yeni olanı eski olana dönüştürerek, bilinmeyeni bilinene indirgeyerek 'sınırlandırır' ve babanın kurduğu tahakkümü dolaylı olarak yeniden üretirler. Böylece, çocuklar 'yeni' hiçbir şey öğrenemezler, tersine, babanın kurduğu anlamlandırma rejiminin içinde fasit daire çizmeye devam ederler. Çocukların eğitimde kullandıkları kaset kaydının 'işitsel bir sözlük' olduğu unutulmamalıdır. Dilin bu türden göndergesel olmayan ama 'ayrımsal' yapısı dilin ontolojik konumunu şiddetle sarsar. Evrensel, nesnel, mutlak bir 'hakikat', eğer nesneye ait ise, dilde bulunamaz. Bir başka ifade ile, dil denilen apparatus dış dünyanın koşulu anlamında aşkınsal değildir veya dildeki anlam nesneye içkin değildir. Derrida ve Lacan, gösteren ve gösterilen arasındaki keyfi ilişkiyi, anlamın uzlaşımsal yapısını ortaya koyan Saussure'ün bu iddiasını bir adım daha öteye taşıyarak, dilde dış dünyaya gönderim olmadığı gibi, 'gösterenin' de bulunmadığını, gösterge zincirinde bir gösterenin bir başka göstereni imlediğini iddia ederler. 
Bu durum, 'anlamın keyfiliği/rastlantısallığı' sonucunu da doğurur: Anlam dile iktidar ilişkileri yoluyla atanır. Zaten Derrida'nın yapı-söküm ile yaptığı şey, gösteren ile gösterilen arasındaki bu keyfiliği ifşa etmektir. Sonuç olarak, gösterge sistemi (dil) ile dünyaya getirdiğimiz düzenin ve açıklamaların/anlamlandırmaların kesin, mutlak ve zorunlu olduğuna dair herhangi bir güvencemiz yoktur. Köpek Dişi filmi, bu 'güvencesizliği' kayıt altına alır.

Dilin ayrımlar üzerinden yapılanması bu makalenin teması açısından hayatidir. Ayrımların dünyaya değil ama dile ait olması, yani, dünyadaki ayrımların aslında gösterge sisteminin kendisinden kaynaklanması, evin 'içerisi-dışarısı' ayrımına da ş̧ık tutar. Ayrımın olgusal değil, kurgusal doğası, dış dünyaya atfettiğimiz bütün ayrımları spekülatif hale getirir. Ancak, bu ayrımlar hala öznenin düşünce biçimini, dünyayı görme biçimini belirler. Çünkü, Lacan'da “özne”, dildeki bir konumdur, başka bir ifadeyle, simgeselin/dilin etkisidir (Lacan, 2005b: 708-709). Dolayısıyla özne, dilin kendi içindeki görünümlerini, dış dünyaya ait ontolojik hakikatler olarak görür/kavrar. Bu anlamılla dil, dünyayı veya gerçeği aktarmakla mükellef, onu mülküne alan öznenin denetiminde pasif bir iletişim aracı olarak kavranamaz; tersine dil, bir dolayım olarak, kendi gerçekliğini üretir. Bir başka ifade ile, dil dış dünyayı temsil etmez, onu kurar. Şimdi, özne'nin dil tarafından belirlenmesi/üretilmesi, 'kendilik' bilincinin, kimliğinin, değerlerinin gerçek düzlemde değil, söylemsel düzlemde yapılandırıldığı anlamına gelir (Lacan, 2005: 590). Dünyaya getirdiğimiz düzen, aslında bizim değil, 'dildeki gösterenin düzenidir', bir başka ifadeyle, büyük Öteki'nin düzenidir. Köpek Dişi'nde baba çocuklara dili kendi söylemsel düzlemine göre öğretirken, aslında, çocukları belirli/somut özneler olarak üretir. Çocuklar dünyayı 'babalarının söylemi' dolayımıyla anlamlandırırlar. Dilimizin sınırları, o halde, düşüncelerimizin sınırlarını da belirler. Filmdeki bir sahnede erkek kardeş Christina'ya gördüğ ü rüyayı anlatır: “Annem havuza düşüyor” der, susar ve sahne biter. Akay, verdiği seminerler sırasında Lacan'ın konuşurken aralarda uzun uzun 'sustuğunu' belirtir ve bu 'susmanın' kendisinin de bir 'gösteren' olduğunu iddia eder (Akay, 2018:138). Benzer şekilde yorumlayacak olursak, bir gösteren olarak çocuğun susması, dilinin sınırının rüyasının da sınırı olduğunu gösterir. Lacan'ın sisteminde bebek, 'dışsallığı' ilk olarak imgesel düzeyde ayna evresinde, aynada gördügü imago ile kendini özdeşleştirerek deneyimler. Ancak simgesel düzeyde içerisi ve dışarısı ayrımı ya da karşıtlığı dilsel göstergeler sistemine girişle ortaya çıkar. Lemaire, linguistik simgesellikten, sosyal simgeselliğe geçişin eş zamanlılığını vurgularken, dilin özneyi kurduğu süreçte gerçekleştirdiği ilk ayrımın 'içerisi' ile 'dışarısı' ayrımı olduğunu vurgular. Dil bunu yaparken, özne ile 'ötekiler' arasına bir dolayım olarak sınır çizer (Lemaire, 1977: 57-59). Kendimi, diğer öznelerden ayırıp, 'ben' diyebilmemin önkoşulu dildir, kendimi ancak diğerlerinden ayrıştırarak kurabilirim. Böylelikle, simgesele girdiğim ilk düzlem olan ailenin 'öznesi' olurken, aile dışında kalanları, ilk etapta, 'öteki', 'yabancı', 'düşman' olarak kodlarım. Öteki özneler ile ilişkimiz dil dolayımı ile belirlenir. Dolayısıyla, filmde ailenin 'evin içerisi ve dışarısı' ayrımını bu derece keskin ve yıkıcı bir biçimde belirlemeleri, evin dışını bir tehdit alanı olarak görmeleri, aslında, dilin işlevinin bir sonucudur (dilin "ayrımsal" yapısı). O halde, evin içerisi ile dışarısı arasındaki sınır, aslında, dilin yarattığı sınırdır. Wittgenstein'ın tespitini bağlamından kopartarak, ya da kasten yanlış okuyarak, buradaki duruma tercüme ederek söyleyecek olursak "dilimizin sınırları, dünyamızın da sınırlarıdır" (Wittgenstein, 2006: 5.6)..$^{*}$ Buradaki denkleme uygun bir

6 Wittgenstein Tractatus-Logico Philosophicus'ta bu cümleyi kurarken amacı Lacan'ın tam tersi bir biçimde dilde anlamın tümüyle 'gönderimsel' olarak ortaya çıkması gerektiğini göstermeye çalışmaktır. Böylece, bir 'ideal-dil' kurmaya çalışarak mantıkçı pozitivizmin 'meta-dil' anlayışını sahiplenir. Daha sonra Felsefi Soruşturmalar metninde 'resim teorisi' yaklaşımını reddedip, dili ‘uzlaşımsal' bir yapı olarak ele alır. Öte yandan Lacan, 'Ötekinin Ötekisi' 
biçimde, evin dışındaki 'öteki' veya 'yabancı', anne ve baba tarafından evin düzenini bozan 'bir tehdit' olarak algılanır. Buradaki analizimize çok benzer şekilde, Zizek, Robert Heinlein'ın Unpleasant Proffession of Jonathan Hoag kitabını incelerken, kitapta yer alan arabanın 'içerisi' ve 'dışarısı' ayrımını, iki farklı gerçeklik düzlemi olarak ele alır. Buna göre, arabanın içindeyken, dışarısının "korkunç" ve tehlikelerle dolu gözükmesinin sebebi, arabanın dışındaki dünya ile içindeki dünyanın uyumsuzluğudur. Kitaptaki karakterler, arabanın içindeyken, dış dünyayı, "bir başka gerçeklik tarzı" olarak algılarlar. Bu yüzden, içerisi ile dışarısı arasında bir "sınır" olarak araba camının kapalı olması, karakterleri güvende hissettirir (Zizek: 2005: 30-31). Tehdit hep araba camının öte tarafından, dişarıdan, içeriye doğru sızmaya çalışır. Paralel olarak, filmde de evin dışındakilerin gerçeklik düzlemi (dili, gösterge sistemi) aileden farklıdır, dolayısıyla 'nesnelerin düzenlenişi' ve 'dünya' da farklıdır. Tehdit, dili farklı konuşanlardan, yani 'dışarıdan', 'evin içine doğru' yönelir. Bu tehdidi bertaraf edebilmek için, dışarının içeriye sızmasını/sirayet etmesini önlemek için, evin bahçesinin etrafına yüksek çitler çekmek yeterli değildir, baba eve getirdiği bütün malzemelerin üzerinde yazı bulunan ambalajlarını da söker. Filmde, babayı harekete geçiren mekanizmanın birebir yansımasını yaşadığımız dünyada da görebiliriz: Hepimizin bildiği üzere Trump, Meksika sınırına dışarıdan gelecek 'yabancılara', 'tehdide' karşı, yani, 'dışarıdan içeriye sızmaları' engellemek için bir 'duvar' örmeyi önermektedir. Yaptığı bir açıklamada bu hamlesini gerekçelendirirken, çok isabetli bir biçimde, 'ev' örneğini verir: "Evimizin etrafını da güvenliğimiz için duvarla örmüyor muyuz?" Burada vurgulanması gereken önemli nokta, 'dil' ile ırkçılık, zenofobi, islamofobi gibi her türden ayrımcılık, 'öteki korkusu' arasındaki ilişkidir. Bizimle aynı dili konuşmayan, farklı olandan korkarız. Sonuç olarak, filmdeki 'evin içerisi-dışarısı' ayrımının sorumlusunun 'dil' olduğu, böylesi bir karşıtlığın, dilin soyut işlevinin öznedeki somut tezahürü olarak ortaya çıktığı bir kez daha vurgulanmalıdır.

Ancak yine paradoksal bir biçimde, Lacan'ın vurguladığı nokta, aslında 'dil'in kendisinin 'yabanci' olduğudur. Dil, her şeye rağmen 'öteki' dir. Ana dil, 'ötekinin dilidir' (Fink, 1995: 7). Ana dilimiz, en başta bize 'dışarıdan' öğretilir, bize ait değildir (ve hiçbir zaman bize ait olmaz). Dili konuştuğumuzda 'ötekinin söylemine' dahil oluruz, yani, özne oluruz. Lacan açısından, özne olmak demek simgesel ağa girmek demektir. Lacan' da 'özne'nin kaçınılmaz olarak bölünmüş olmasının anlamı da budur. "Özneden çıkıp mevcut hale gelebilen ne varsa hepsine hükmeden gösterenler zincirinin yer aldığı mahal” (Lacan, 2014: 216) olarak 'büyük Öteki' özneyi üretirken, “Öteki'nin söylemi” bilinçdışının ortaya çıktığı düzlemdir (Lacan, 2014: 139). Bu yüzden Lacan öznenin, bilinçdışında sözün etkisi olarak ortaya çıktığını söyler. Bu denklemde, bilinçdışı da, "sözün özne üzerindeki etkilerinin toplamı" olarak ele alınır (Lacan: 2014: 134). Büyük Öteki'ne, simgesele girişin tarihsel momenti, Oedipal'in çözülüşü ile, yani babanın çocuğa 'Hayır!'ı ile başlar. Lacan'ın "Babanın-Adı”, “Babanın-Yasası” dediği kavramsallaştırmanın kökeni de bu 'hayır' dır. ${ }^{7 *}$ Böylelikle, "Babanın-Adı" ya da "BabanınYasası" (patriarkik yasa), simgesel düzlemde "asli (fundamental) gösteren" olarak işlev görür. Babanın-Adı'nın bu türden "paternal işlevi", dildeki anlamlandırma zincirinde "point de capiton" olarak ortaya çıkar. Bir başka ifade ile, dilde anlamı sabitleyeceğimiz bir gösteren ya da gönderim bulunmadığı için, gösterenler zincirinde anlamı sabitleyebileceğimiz bir uğrak olarak "point de capiton", 'anlam'1 zincirdeki bir gösterene "diker", yani, "babanın-

olarak böyle bir 'meta-dil' in mümkün olmadığını açıkça belirtir (Lacan, 2005b: 688).

7 Lacan, Fransızca'daki 'ad' (nom) ile 'hayır' (non) kelimelerini "babanın adı" (le nom du pere) ve "babanın hayır" 1 (le non du pere) kavramsallaştırmasında kullanır. 
adı" gösterene o anlamı tayin eder. Bu anlamıyla Baba, simgesel ağda, "Yasa'nın otoritesinin ilksel temsilcisidir" (Lacan, 2005b: 688). Ancak Lacan, "Babanın-Adı/Babanın-yasası" derken, kastının "gerçek, somut bir baba" olmadığını, onun simgesel işlevi olduğunu israrla belirtir. Öte yandan, film kurduğu yapı ve kapalı evreni sayesinde çok zor bir işi sinematik olarak başarır. Lacan'ın üç kategoriye ayırdığı "baba” kavramını (İmgesel Baba, Simgesel Baba ve Gerçek Baba), üç fonksiyonunu tek bir babaya yükleyerek "kişiselleştirir". Filmde babayı izlerken, bu anlamıla, aynı zamanda özneyi üreten, anlamı inşa eden "büyük Öteki"ni de izleriz. Köpek Dişi'nde babanın yasasına en çok itibar gösteren çocuğun erkek kardeş olması bu anlamıla tesadüf değildir. Oedipus'un çözülüşünde babayla aşırı-özdeşleşen erkek kardeş, babanın paternal anlamlandırma rejimine tümüyle teslim olmuştur. Babanın sorularına hep en doğru cevabı vermek için çırpınır ve verir de. Babayla bu aşırı-özdeşleşmenin bir gösterisi olarak Lanthimos, gece uyuyamayan erkek kardeşin ebeveynlerinin yatak odasına giderek anne-babasının arasına yattığını ve babasına sarılarak uyuduğunu izleyicilere gösterir.

Bütün bu açıklamalar ışığında temel sorumuza tekrar geri dönelim: O halde, bizim 'pseudo-gerçek' anlamlandırma rejimimizi, filmdeki patolojik ailenin anlamlandırma rejiminden daha gerçek, daha doğru kılan nedir? Vereceğimiz cevabın belirleyeni dilin ya da anlamın kendisi olamayacă̆ına göre, belirleyenimiz, tuhaf bir biçimde, niteliksel değil, niceliksel olacaktır. Filmde, sınırı 'evin bahçesini çevreleyen çitler' ile çizilen dünyada babanın üreticisi olduğu anlam rejimini kabul edenlerin sayısı (4 kişi), dışarıdaki dünyanın gösterge sistemini kabul edenlerin sayısına göre çok daha azdır..$^{8^{*}}$ Hakikatin bu şekilde nicel belirlenimi ile Douglas Adams'in bilim-kurgu klasiği olan romanından uyarlanan Otostopçunun Galaksi Rehberi' ndeki bir sahne arasında kuracağımız paralellik, bu nicel karşılaştırmanın anlamsızlığını bizlere gösterecektir. Bu sahnede, evrendeki her şeyi bildiği varsayılan bir süper-bilgisayarın "hayatın anlamı/hakikati nedir?" sorusuna verdiği yanıt 42 ' dir. Bu yanıt ne kadar tuhafsa, bizim de filmdeki "ailenin" yanlışlığını sayısal olarak belirlememiz en az o kadar tuhaf olacaktır. Yukarıda, dünyayı anlamlandırma biçimimizin doğru ve gerçek olduğu bize apaçık gelmesinin sebebinin, zaten dünyaya 'o' paradigma ile bakmamız olduğunu söylemiştik. $O$ halde, bunun böyle olduğunu göremememizin sebebi nedir? Dilin ve kültürün tahakkümü tek yönlü ve asimetriktir: Kendi mekanizmaları ile ürettikleri öznelere kendilerini 'şeyleri düzenleyen tek ve mutlak anlamlandırma rejimleri' olarak dayatırlar. Foucault açısından söyleyecek olursak, tahakkümün bize "tahakküm" olarak değil ama rasyonel/mantıklı bir düzenek olarak görülmesinin sebebi, bunun rasyonel olduğu bilgisinin (dispositif olarak episteme) yine bu tahakküm ilişkileri yoluyla üretilmesinden kaynaklanır (Foucault, 2005). Aileyi ve onu kuran nesneleri, yani 'anneyi, babayı, kardeşleri', nasıl anlamlandıracağımızı yine ailede öğreniriz. Filmde çocuklar tarafından babanın tahakkümü 'dışarıdan kendilerine yönelen' disipline edici mekanizma olarak görülmez, tam tersine, çocuklar bu tahakkümü 'talep ederler'. Panoptikon'da olduğu gibi, dışarıdan özneye yönelen disipline edici bakış, bir süre sonra dışarda bulunmasına gerek kalmadan, öznenin kendi içsel/kendisinin kendisine yönelik bakışına dönüşür. Babaya en çok itaat eden çocuk olarak erkek kardeşin, babasıyla arasındaki bu ilişkiyi 'itaat' olarak değil, 'ittifak' olarak tanımladığını söylemek yanlış

8 Pre-linguistik dönemde, anne ile çocuk arasında toplumsal olana kapalı son derece 'mahrem' bir ilişki vardır. Dil dünyasına girişle ve oedipal'in çözülüşü ile birlikte bu mahremiyet ilişkisi yıkılır ve çocuk anneden kopar. Böylelikle, çocuğun anneyle yaşadığı bu toplum-dışı/mahrem ilişki simgesele girişle sonlanır. Çocuk özneleşmeye başlar. Anneden kopuşuyla birlikte, çocuk artık 'annenin arzusunu arzular', anne tarafından 'tanınmayı' arzular. Anne ile çocuk arasına 'arzu dolayımı' girer. Filmdeki ailenin açmazı, anne ve çocuk arasındaki bu mahrem ilişkinin yalnızca babayı da içine alacak kadar çözülmesi, dışarı taşamaması ve toplumsallaşamamasıdır. Anneçocuk arasındaki mahrem ilişki, aile arasındaki mahrem ilişki olarak sabitlenir. 
olmayacaktır. Büyük kız kardeşin evin dışına çıkması bile bir itiraz, isyan veya kaçış değildir. Babanın koyduğu kuralları harfiyen uygular; köpek dişini kırar, arabanın bagajına girer. Babanın yasası zedelenmiştir ama hala 'oradadır'. Dolayısıyla, mekanizmanın en görünür yerde gizlenen bu illüzyonunu, tahakkümü, yine de göremeyiz. Filmin birkaç sahnesinde, içerişi-dışarısı sınırını belirleyen bahçenin açık kapısına kadar gelen çocuklar, o eşikte dururlar, dışarıya bakarlar ama dışarı çıkmazlar. Zizek, Lacan'ın "Çalınan Mektup" analizini yorumlarken, buradaki asıl vurgunun, çalınan mektubun baştan beri orta yerde gizlenmesinden hareketle "gösterenin saçmalığı" olduğunun altını çizer (Zizek, 2006: 30).

'Gerçek' ile 'kurgu' arasındaki mesafenin düşündüğümüz -ya da ironik bir biçimde söyleyecek olursak- 'kurguladığımız' gibi olmaması, bir başka ifadeyle filmde babanın kurduğu gerçeklik düzlemi ile bizim 'gerçekliğimiz' arasındaki farkın düşündügüumüz gibi ontolojik bir fark olmaması, filmdeki bir paradoksu da görünür kılar. Büyük kız kardeşin arabanın bagajında kaçtığı dış dünya da aslında 'gerçek' değil bir başka 'kurgu dünya' dır. Bu paradoks Köpek Dişi filmini Truman Show gibi 'gerçek' ile 'kurgu' arasındaki ilişkiyi sorunsallaştıran diğer filmlere de yaklaştırır. Kızın araba bagajında evden çıkışı ile, Truman'ın sahne dekorunu yırtıp 'gerçek dünya' ya girmeye hazırlandığı sahne aynı paradoksu içerir. Gittikleri 'dünyanın' da söylemsel olarak 'üretilmiş' olduğu gerçeği ya da bir 'kurgu' dünyadan diğerine kaçış paradoksu. Lacan, 'gerçek' (the Real) ile 'gerçeklik' (reality) kavramlarını birbirinden radikal bir biçimde ayrıştırır. 'Gerçek', bizim onu kavramamızdan tümüyle bağımsız olarak var olan, dolayısıyla nesnel, doğal ve neredeyse 'kendinde-şey' olarak, bizim erişimimize/temasımıza kapalı olandır. Lacan, Ecrits'te Hegelci yorumlarının büyük etkisinde kaldığı Hyppolite'in Freud'un Verneinung kavramını ele alma biçimini eleştirirken gerçek'e atıfta bulunur: Gerçek, simgesel temsile direnendir, simgeselin dişında olandır (Lacan, 2005b: 324)..$^{*}$ Buna mukabil, gerçeklik, toplumsal olarak yapılandırılan, simgesel alanın içinde, kültür dünyasına ait olan, dil ile kurulan, dolayısıyla tarihselleştirilen bir söylemsel inşaadır. O halde, gerçek ontolojik bir kategori iken, gerçeklik tarihsel ve üretilmiş olandır. Yani bizim gündelik hayatta 'gerçek' dediğimiz fenomen aslında Lacanyen anlamda 'gerçeklik' kavramına karşılık gelir. Tam da bu yüzden, neyin gerçek neyin kurgu olduğunu saptayabilecek 'nesnel' koşullardan yoksunuzdur. Çünkü gerçekliğin kendisi toplumsal olarak üretilmiş sosyal bir inşaadır. Lacan "gerçeklik ilkesi" nden bahsederken, Freud'dan farklı olarak 'doğal' olana değil, bu türden kurgulanmış veya 'dolayımlanmış' gerçekliğe işaret eder (Fink, 1995: 226). Yukarıda 'içerisi-dışarısı' karşıtlığı bağlamında Zizek'e değinmiştik. Zizek Lacanyen "gerçek" in, tam da bu 'içerisi-dışarısı' arasındaki "sınırda" bulunduğunu belirtir (Zizek, 2005: 30). O halde, gerçek, Köpek Dişi'nde, evin içerisi ve dışarısı hattını çizen 'sınırdır' ya da 'sınırdadır'. İki farklı simgesel düzlemi ayıran ama her ikisinin de bulunmadığı o nötrlük-hiçliktir. Çünkü, farklı simgesel düzlemlerin ortaya çıkabilmesinin önkoşulu gerçek'in simgeselleştirilememesidir.

Filmde, 'ritüeller' dikkat çekici derecede belirgindir. Aile değerlerini vurgulayan bu ritüeller, biliyoruz ki, evin dışındaki dünyada da özneliği ve tabiyeti üreten performanslardır. Filmde, tıpkı 'dışarıdaki dünyada' olduğu gibi, aile olarak akşam yemeği yemek son derece önemlidir. Yemek yemeden önce ailenin bütün fertleri özenle bu seküler ayin için hazırlanır. Yemeğin öncesinde hazırlanma evresi, yemeğin kendisi ve yemek sonrası yapılacak aktiviteler, aile olmayı yeniden üreten ve nasıl 'iyi' aile olunacağını gösteren ritüellere dönüşür. Ritüeller,

9 Lacan'ın sistemine böylesi bir kategorinin, yani dil, söylem ve tarih dışı, sabit ontolojik bir kategorinin kabul görmesi, bir başka ifade ile, bir tür 'özcü' (essentialism) yaklaşımı sistemine dahil etmesi, post-yapısalcı çizginden ayrışmasının temel sebebidir. 
böylelikle, aile değerlerini ve normlarn fetişleştirmenin performatif bir göstergesi olarak işlev görür. Althusser bağlamında ele aldığımızda, bu ritüellerde yer almanın, ritüellere "çağırılmanın", yani Devletin İdeolojik Aygıtı olarak ailenin “özneyi çağırması"nın, özneyi üreten/kuran bir edim olduğunu söyleyebiliriz. ${ }^{10}$ Zizek' in bu konuyla ilgili yorumunu filme uyarlayacak olursak: Akşam yemek masasına oturduğunda, ailenin normlarına inandığın için oturduğuna inanacaksın (Zizek, 2006: 60). Filmdeki yemek sekanslarında babanın sorduğu sorular ile çocukların "bu ailenin özneleri" olduklarına dair inançlarını pekiştirmeye çalıştığını görüyoruz. Lacan'a benzer şekilde, Althusser açısından da özne, özerk, tözsel bir kategori değildir, "çağırılmanın" etkisi olarak ortaya çıkan bir epiphemenondur. Çağrıya cevap vermek ile özne olarak üretilmek zamansal olarak ardışık değil, neredeyse eşzamanlıdır. Film, ritüellerin bu türden işlevselliği dışında kendi başına anlamsızlığını "cenaze töreni" sahnesinde gösterir. Söz konusu cenaze töreni, "aslında hiç var olmayan" ağabey'in ölümü üzerine düzenlenir. Baba, gerçek olmayan ağabey hakkında gerçek olmayan hikayeler anlatır. Gerçek olmayan ağabey, zamanından önce, yani köpek dişi düşmeden evden ayrıldığı için, evin dışında bulunan ve gerçek olmayan devasa büyüklükteki kedi tarafından parçalanmıştır. Törende çocuklar da hiç görmedikleri ağabeyleri hakkında konuşma yapar. Ritüelin bir parçası olarak, kediyi dışarıda tutmak için babanın komutuyla elleri üzerine eğilerek köpek gibi havlarlar. Bu sekansta iki noktanın altı çizilmelidir: Ritüeldeki bedensel performansların aşırılığı ve 'ailenin geçmişinin baba tarafından icadı'. 'İcat edilmiş geçmiş' sayesinde, çocukların dünyaya ve aileye dair 'hafızaları tazelenir'. 'Yeniden hatırlatma', çocukları 'ailenin çocuk özneleri' olarak üretirken, aynı zamanda şimdi ile geçmiş arasındaki bağı kurup ‘bütünlüklü özneler' olarak da yapılandırır. Diğer yandan, 'icat edilmiş aile tarihi', ya da Hobsbawm'ın kavramsallaştırması ile, "geleneğin icadı" yoluyla otorite (baba), otoritesi altındakileri rehabilite eder, odağında kendisinin koyduğu değerlerin olduğu toplumsallığı (aile) ve toplumsal ilişkileri yeniden üretir, böylelikle otoritesini yeniden onaylatır ve bu onay üzerinden kendi gücüne meşruiyet devşirir.

Çocuklar arasında cinsel ilişkiye girme hakkına sahip tek kardeş olan erkek, cinsel birleşmeden önce bizzat baba tarafından 'hazırlanır'. Kız kardeşlerin cinsellikleri ise tümüyle görmezden gelinir (Aile tüm hatlarıyla ataerkildir). Bu çarpıcı sahnelerde cinsel birleşme 'haz almak' için değil, 'erkeğin yerine getirmesi gereken bir vazife olarak' gösterilir. 'Erkek olmanın' koşulu olan cinsel ilişkiye girme edimi 'babanın talebidir'. Burada çift yönlü gösterge ekonomisi işler: Babanın bu talebi, çocuğun baba tarafından onaylanma talebidir aynı zamanda. Arzu, her zaman "arzu için arzudur", bir başka ifadeyle, arzu "Babanın-Yasa'sına tâbi olan Öteki' nin arzusu için arzudur" (Lacan, 2005b: 723). Babanın talebi, erkek çocuk tarafından son derece nizami bir şekilde, sessizce, bir görev olarak ve mekanik bir biçimde yerine getirilir. Sevişme sahnelerinde neredeyse 'cinsellik' yoktur. Böylelikle de Lanthimos, Lacan'ın "cinsel ilişki diye bir şey yoktur" (Lacan, 1999: 17 ve 34) önermesini sinematik imgeler yoluyla son derece başarılı bir şekilde izleyiciye gösterir. Lacan açısından cinsel ilişki yoktur, çünkü konuşan varlık olarak insanlar arasında dolaysız, doğrudan, içgüdüsel cinsel ilişki imkansızdır. "Cinsel jouissance ile doğrudan karşılaşabilir miyiz? Karşılaşamayız, işte bu yüzden konuşma var" (Lacan, 1999: 32). Bu imkansızlığı yaratan temel koşul, cinselliğin de dil ile dolayımlanmış olmasıdır. Onu simgeselleştirebiliyor isek, yani onu simgesel düzlemde anlamlandırabiliyor isek, artık o gerçek'in alanı değildir. Çünkü biliyoruz ki, gerçek, simgesel olanın tamamen dışındadır; "simgesel alanda ortaya çıkmayan, ancak gerçek'te ortaya çıkar" (Lacan, 2005b: 388). Cinsellik,

10 Bu noktaya Tyrer (2017: 118) de vurgu yapar. 
Ötekinin alanındadır, yani, "onun hakkında yapılan açıklamaların” alanındadır. "Daphnis, sevişmek için ne yapması gerektiğini kendisinden öğrenmesi gerekirken, ihtiyar kadından öğrenir" (Lacan, 2014: 211). Cinsel ilişki her zaman Öteki'nin söylemi ile dolayımlanmıştır (Lacan, 1999:41-45 ve 83-88). Bu dolayım sebebiyle, cinsel ilişki artık içgüdüsel değil, dürtüseldir (öğrenilmiştir). Örneğin Lacan "bakış" (gaze) meselesini tartışırken gündeme getirdiği “skopik dürtü", açıktır ki, biyolojik tabanlı, kaynağı biyolojik olan bir içgüdü değildir. Benzer şekilde, Lacan, libido'nun da cinsel bir içgüdü olmadığını 1srarla vurgular (Lacan, 2005b: 722). Filmde de erkek kardeşin cinselliği "baba" dolayımı ile gerçekleşir. Erkek kardeşin sevişmesi, aslında kendisinin değil, Öteki'nin (babanın) arzusudur. Christina, o odada babanın arzusunun göstereni konumundadır. "Bir gösteren, bir özneyi bir başka gösteren için temsil eder" (Lacan, 2014: 219). O halde, yukarıda yaptığımız vurgu ile söyleyecek olursak, Lacan'da ne gerçeklik ilkesi 'gerçekle' ilgilidir ne de cinsellik 'dolaysız cinsellikle' ilgilidir.

Lanthimos harikulade bir taktik uygulayarak film boyunca ikircikli bir tutum alır. Hem ailenin 'bizden' farkını kışkırtıcı sahnelerle gösterir, ama aynı zamanda filmdeki aile ile aramıza açık bir mesafe koymamıza tam olarak izin vermez. Film babayı 'sapkın' olarak göstermekten özenle kaçınır. Baba, kelimenin tam anlamıyla kusursuz bir aile babasıdır. Karısına tümüyle sadıktır, Christina ile olan ilişkisi son derece tanımlı ve mesafelidir, çocuklarına karşı cinsel en ufak bir eğilim göstermez, bu da izleyiciyi rahatsız eder. Çünkü Lanthimos bir hamle yapıp babanın, örneğin, çocuklarına cinsel istismarda bulunduğuna dair küçük bir imada bulunsa, izleyiciye aileyi mahkum edecekleri tartışmasız bir alan açmış olurdu. Ama film bu hamleyi yapmaktan özenle kaçınır. Babanın 'sapkın' olmayışına dair, Zizek'in "sapkın” ile "histeriknevrotik" arasında başka bir bağlamda yaptı̆̆ı keskin ayrımı takip ederek söyleyecek olursak, baba bir sapkın değil, tam tersi histeriktir. Sapkın, simgesel yasakları sürekli ve fütursuzca ihlal eder ve bunu yaparken neyin keyif verip vermeyeceğini bilir (Zizek, 2003: 295-296). Bu anlamıla sapkın tümüyle bireyseldir, her ediminin tek temel referansı yalnızca kendisidir. Kendisi yasak koymaz, tersine konulan yasakları ihlal eder. Bir başka ifade ile, sapkın, organize olarak başka bir simgesel düzen kurmamaktadır. Öte yandan filmdeki baba'nın en büyük arzusu 'ailesini korumak, güvenliği sağlamak, ailesini bir arada tutmaktır', bunu sağlayabilmek için de sürekli yasaklar koyar. Diğer simgesel düzlemlere sızmak, onları ihlal etmek gibi bir gündemi yoktur. Kendi kurduğu sistemin doğruluğundan ve gerçekliğinden emindir. Lacan'ın tanımıyla, baba bir histerik olarak, yani “Öteki'nin eksikliğini Öteki'nin talebi ile özdeşleştirerek" (Lacan, 2005b: 698) 'ailesini dışarıdan koruma' saplantısı geliştirir. Baba Christina'yı ailesine zarar verdiği için cezalandırırken, "oyunumu bozdun" demez, tam tersine, "umarım senin çocukların da bunları yaşar ve kötü alışkanlıkları olur, bu da aileme yaptıklarının cezası" der.

Filmdeki bir başka çarpıcı sahne, akşam yemeğinden sonra babanın çocuklara büyük babalarının yazdığı ve söylediği şarkıyı plakla dinlettiği sahnedir. Aile yine huzur içinde ve bir arada şarkıyı dinlerken, baba İngilizce olan sözleri Yunanca'ya "kendi söylemsel düzlemi" üzerinden tercüme eder:

"Babamız bizi sever (fly me to the moon), annemiz bizi sever (Let me play among the stars). Biz onları sever miyiz? (Let me see what spring is like on), Evet severiz. (Jupiter and Mars), Kardeşlerimi çok severim (In other words, hold my hand), Çünkü onlar da beni sever (In other words, baby, kiss me), Ailem benimle gurur duyar (Fill my heart with song), Çünkü tüm gücümle çalışırım (And let me sing for ever more), Ama hep daha iyisini yapmak için 
uğraşırım (You are all I long for). Evimiz çok güzeldir ve onu severiz, seni asla terk etmeyeceğiz (All I worship and adore)."

Elbette dinlediğimiz şarkı büyükbabanın değil, Frank Sinatra' nın “Fly Me to the Moon" şarkısıdır. Bu sahnede sarsıcı olan sadece dilin kullanımı değildir. Şarkıdaki göstergeler ekonomisinin çocuklara nasıl temellük edip onları özne olarak yeniden kurduğu, Lanthimos tarafından, tartışmaya yer bırakmaksızın görselleştirilir. Üç kardeş şarkı sözlerinin ilgili yerlerinde 'bakış' yoluyla birbirlerini 'sadece sevdiklerini değil ama aynı zamanda sevmeleri gerektiğini' gösterirler. Böylelikle çocuklar, neyi sevip neyi sevmeyeceklerini, neyi ne kadar seveceklerini ötekinin söylemi dolayımıla öğrenirler. Burada bir kez daha büyükbabanın 'sahte' şarkısı üzerinden ailenin geçmişi icat edilir. Babanın bu taktiksel hamlesi tarihsel olarak başvurulan neredeyse standart bir uygulamadır. Başka bir ifadeyle, bu sahnede "oldukça tuhaf" bulduğumuz babanın bu davranışı, aslında, dışarıdaki dünyada da toplumsallığı kuran düzeneğin işlevsel bir parçasıdır. Filmdeki ve bizim dünyamızdaki hem anlamı tayin eden hem de bireyleri özne olarak tahkim eden mekanizma ortaktır. Geçmişin İcadı metninde Hobsbawm, genel olarak kültürde eski içeriklerin/malzemelerin, özel olarak da retorikte kullanılan "geleneksel topoi" nin nasıl kesintiye uğratıldı̆̆ını, bu içeriklerin tarihsel olarak ortaya çıkmış yeni koşullarda işlevsel olabilmesi için yeni ihtiyaçlar ve amaçlar doğrultusunda deforme edilerek nasıl yeniden üretildiğini -tıpkı bu sahnede babanın eski bir şarkıyı kendi amacı doğrultusunda deforme edip yeniden üretmesi gibi- ve 'icat edilmiş geçmişin' yapılandırılması için nasıl kullanıldığını gösterir. Bu durumu da filmle çok benzer şekilde, eski ve bilinen "şarkı ve ilahilerin" deforme edilerek dönüştürülmeleri örneği üzerinden somutlaştırır (Hobsbawm, 2012: 7-9). Kültür dünyasındaki bu türden yerinden etmelerin/yeniden kurmaların imkanını yaratan temel koşul, açıtır ki, simgesel düzenin özsel/doğal değil ama üretilmiş/kurgusal yapisidir.

KöpekDişi,buörneklerindışında,Lacan'ın “arzu” tanımını, “arzununherzamanÖteki' nin arzusu" olmasını vecinsellikalanında bile "neyi arzulayıp, neyi arzulamayacağımızı" içgüdüsel belirlenmediğini, tam tersine, simgesel düzlemde gösterenler zincirinde öğrendiğimizi bir kez daha kusursuz bir biçimde gösterir. Buna göre, büyük kız kardeş, Christina'nın eve yanında getirdiği fosforlu saç bandını elde edebilmek için Christina'nın talebi üzerine oral seks yapar. Daha sonra, Christina eve tekrar geldiğinde, büyük kız kardeşe yanında saç jölesi getirdiğini yine kendisini yalarsa bunu ona vereceğini söyler. Böylelikle, büyük kız kardeş, kendi arzu nesnesini elde etmek, karşısındakinin cinsel arzusunu yerine getirmesi gerektiğini öğrenir. Daha sonra, diğer kız kardeşten bir şey istediği zaman, karşılığında onu "yalamayı" vaad eder, kardeş bunun ne anlama geldiğini anlamaz ancak yine de kabul eder. Büyük kız kardeş, bunun üzerine cinsel bir jest olarak yanlış bir alanı, kardeşinin 'omzunu' yalar. Bu sahnelerde hem gösterenler zincirinde arzu ekonomisinin nasıl yapılandırıldığını, hem de cinselliğin aslında öteki dolayımı ile nasıl öğrenildiğini bir kez daha görürüz.

Bir şeyi adlandırmak demek o şeyi anlamlandırmak demektir ve tam tersi (dünyayı anlamlandırmak demek, dünyayı adlandırmak demektir). Lacan açısından da, isimlendirilmek bir öznenin kimlik kazanmasını, simgesel düzende tanımlanmasını ve belirlenmesini sağlar. $\mathrm{Bu}$ anlamıla isimler son derece işlevsel gösterenlerdir. Örneğin, Daniel Defoe, orta sınıf bir ailenin çocuğu olarak dünyaya gelir ve gerçek soyadı "foe"dur ancak Fransa'da "De" ön eki üst sınıfa ait olmayı 'gösterdiği' için 40 yaşında soyadını "Defoe" olarak değiştirir (Benzer şekilde Honore De Balzac'ın gerçek soyadı "Balssa"dır ancak daha sonra soyadını "Balzac" 
olarak değiştirir ve "De" ön ekini ekler). Dolayısıyla, isim verirken aynı zamanda nesneleri düzenleriz, isimler yoluyla nesneleri anlamlandırırız. Biz daha doğmadan cinsiyetimize göre ismimiz belirlenir. İsmimiz, bir cinsiyet göstereni olarak simgesel ağda dolaşıma girmiştir. Simgesel düzen, biz daha doğmadan, bizi belirlemek, kayıtlamak, tanımlamak ve özne olarak üretmek için bizden önce "oradadır" (Lacan, 2016: 26). Bu türden isimlerin cinsiyetlendirilmesi, simgesel ile gerçek arasındaki temel bir farklılığı da açığa çıkartır. Gerçek' in mahalinde 'cinsiyet' yoktur (tam da bu yüzden, iç güdü "cinsiyetsizken", dürtü "cinsiyetlendirilmiştir") (Jaanus, 1995: 121). Simgeseldeki anlamıyla 'cinsiyet', ör. 'kadın' veya 'erkek', ontolojik bir sabit değil, dilsel konumlandırmalardır. Ancak biz, isimlere yüklediğimiz anlamları, o isimlere sahip olan öznelere iliştiririz. Baker' in vurguladığı haliyle, "sanki isimler, insan diline ait olmaktansa, şeylere ait zorunda kalmışlar" dır (Baker, 2014: 39). Örneğin, büyük kız kardeş, Christina' dan aldığı filmlerde (Jaws, Rocky, Flash Dance) görerek, kendisine "Bruce" ismini koyar. Kız açısından bir kadın'a "Bruce" isminin konulmasında hiçbir mahsur yoktur, çünkü "Bruce" isminin 'erkek öznenin' göstereni olduğu simgesel alanın tümüyle dışında yaşamaktadır.

Büyük kız kardeşe (Bruce) izlediği filmler yoluyla sirayet eden yeni gösterenler düzeni, kızın kullandığı dili de dönüştürür. Önce, Christina' nın yerine erkek kardeşiyle sevişmek için babası tarafından görevlendirilir (elbette, ailesini koruyan otorite olarak baba, kendi koyduğu ensest yasağını kaldırmaya da muktedirdir), daha sonra cinsel birleşme sırasında canı acıyan Bruce, erkek kardeşine izlediği filmlerden ezberlediği içinde küfürler geçen replikleri söyler. Bir diğer sahnede, büyük kız kardeş, diğer kız kardeşine "bana artık Bruce demeni istiyorum" der, Bruce'un ne demek olduğunu soran kardeşine "bir isim" diye cevap verir (kendisi de bir isim isteyen genç kardeş "belkemiği" kelimesini kendi ismi olarak seçer, ancak büyük kız kardeş buna itiraz eder: “Adın 'bel kemiği' olamaz, bel kemiği bel kemiğidir"). Ve sadece Bruce ismiyle ona seslenirse ona dönüp bakacağını belirtir. Devamında ayağa kalkar, odanın diğer ucuna gider ve kardeşi ona her Bruce dediğinde dönüp bakar. Bu 'ismiyle seslenme ve sese cevap olarak dönüp bakma' jesti üç-dört defa daha tekrarlanır. Bu sahne, Althusser'in "öznenin çağırılması" kavramsallaştırmasının kusursuz bir gösterimidir. İdeoloji, "somut bireylere, somut özneler olarak seslenir" (İtalik, Althusser'in kendi vurgusudur) (Althusser, 2006: 100). "Öznenin ideoloji tarafından üretilmesi" sürecinin bir parçası olarak "özneye seslenme" ve "özneyi çağırma" Althusser'in kendi metninde de bu şekilde aktarılır: Seslenme ve seslenilen öznenin seslenene doğru dönmesi (Althusser, 2006: 99-101). Burada, "öznenin çağırılması" ile Lacan'ın "Che Vuoi?" kavramı arasındaki koşutluğu da vurgulamak gerekir. Che Vuoi, yani “benden ne istiyorsun?", "Öteki benden ne istiyor?" sorusu (Lacan, 2005b: 690), muhatabı büyük Öteki olan ve öznenin arzusunu yapılandırarak mevcut özne konumunda tutan bir mekanizmanın bileşenidir. Bu haliyle, 'çağırılma' durumunda, ideoloji (ya da büyük Öteki) özneye "somut özne" olarak seslenirken, Che Vuoi, süreci tersine işleterek, yani özneyi Öteki'ne seslendirterek aynı işlevi görür.

Son bir nokta olarak, filmde, insanın bedenin bir parçası olarak 'köpek dişi'nin kendisi de hiçbir şeyi simgelemez, bir metafor değildir. Zaten böyle olduğunu, büyük kız kardeşin evden dışarı çıkmadan önce köpek dişini bir ağırlık ile kırdığı sahnede tekrar görürüz. Ancak daha muhafazakar coğrafyalarda, ailenin evinden çıkmanın koşulu olarak, 'köpek dişi', paradoksal bir biçimde, yine aileyi, yani 'evliliğgi' işaret eder. Ailenin evinden çıkmanın tek koşulu yine bir başka aile kurmaktır.

Sonuç olarak, Köpek Dişi filminin, metaforsuzluğu, doğrudanlığı anlamında, bir 'sanat 
ürünü/yapıtı' olmadığı bile söylenebilir. Çünkü bir sanat yapıtı, dış dünyadaki nesnesini olduğu gibi aktarmaz, tersine nesnesini aşar ve bu aşma hamlesi sonucu sanat yapıtı niteliğini kazanır. Öte yandan Köpek Dişi filmi nesnesini aşmaz, aşmak gibi bir niyeti yoktur, nesnesini yalnızca gösterir. Bir başka ifade ile, 'dolayımlanmış gerçeklik deneyimi' (sinema) yoluyla, 'dolayımlanmamış bir gerçeklik deneyimi' izleriz. Tam da bu sebeple, Deleuze' ün vurguladığ "sinematik imgenin dolaysızlığı"nı filmde teknik bir izahata gerek olmaksızın deneyimleriz. Köpek Dişi'nin, Deleuze'ün altını çizdiği haliyle, yani hem hareket ve zamanın dolaysızlı̆̆ı, hem de imgedeki "düşünce" ile karşılaşmamızın dolaysızlığı anlamında, sinematik imgenin "dolayımsızlığının" par excellence örneklerinden biri olduğu söylenmelidir. Dil bağlamında şu noktanın altı dikkatle çizilmelidir: Film, aslında, tümüyle metaforik olanı, dil'in kurucu gücünü ve "paternal metafor"'u (Babanın-Ad1), metafor kullanmadan gösterir. Filmin rahatsız ediciliği de buradan, nesnesini dolaysız olarak göstermesinden, kaynaklanır. Rahatsız edicidir, çünkü metaforsuzluğu, dolaysızlığı ile bize bizim yanlış-bilincimizi, yanlış-tanıma (misrecognition) bağlamında aşırı-gösterir. Filmin bize gösterdiği şeyden ilk başta rahatsız oluruz, ancak nesnemizin bir "sanat yapıtı" olduğunu bilmek bizi rahatlatır. Muhatabımızın bir sanat ürünü olması, onun üretilmiş/kurgulanmış olduğu fikrini bize hatırlatır. Sanatın 'gerçek olmayan' bir 'temsiller sistemi' olduğu fikri üzerinden, 'sanat' ile 'gerçek' arasına bir sınır çizeriz. Köpek Dişi, bu 'sorunlu' ve 'üretilmiş' sınırı güçlü bir biçimde ihlal eder, gücü tam olarak bu ihlalden kaynaklanır.

Lacan, konuşmalarının derlendiği metnin zarfının üzerine neden Ecrits (Yazılarım) yazdığını (ve neden metinlerinin zor okunur olduğunu) şöyle gerekçelendirir: "Benim anladığım anlamda yazı, okunmamak için yazılır. Çünkü başka bir şeyi dile getirir" (Lacan, 2016: 293). Büyük olasılıkla Lanthimos da Köpek Dişi'ni okunmaması için çekti. Çünkü, yine büyük ihtimalle, Köpek Dişi de üzerine yazılanlardan/anlatılanlardan başka bir şeyi dile getirir. Filmdeki çocuklar ${ }^{11^{*}}$, Spivak'ın Gramsci'den devraldığ 1 kavram ile söyleyecek olursak, "konuştuklarında bile kendileri olarak konuşamazlar", "madun (subaltern) konuşamaz" (Spivak, 2010). Çocukların öyküsü "anlatılamaz bir öyküdür", ya da aslında, çocukların “öyküsü üzerine bir sürü öykü anlatılabilir", ama hiçbiri gerçek değil (Coetzee, 1990: 98). O halde, Frank Sinatra'nın şarkısını Lacan ${ }^{12 *}$ (1990: 3) dolayımı ile tercüme ederek bitirelim:

"Ben her zaman doğruyu söylerim (Fly me to the moon), ama tamaminı değil (Let me play among the stars), çünkü tamamı söylenemez (Jupiter and Mars), tamamını söylemek imkansizdır (In other words, hold my hand). Kelimeler bunun için yetersizdir (In other words, baby, kiss me). Tam da bu imkansızlık sebebiyle doğru gerçeğe yaklaşır (Fill my heart with song)".

11 Eğer onları "özneleşmiş bireyler" olarak almayacak isek

12 "Ben her zaman doğruyu söylerim, ama tamamını değil, çünkü tamamı söylenemez. Tamamını söylemek imkansızdır. Kelimeler bunun için eksiktir. Tam da bu imkansızlık sebebiyle doğru gerçeğe yaklaşır". 


\section{Kaynakça}

Akay, Ali, (2018). Felix Guattari: Öznellik Alanları, İstanbul: Otonom Yayıncılık.

Althusser, Louis, (2006). İdeoloji ve Devletin İdeolojik Aygitları. İstanbul: İthaki Yayınları.

Arslan, Ümit Tümay, (2009). "Aynanın Sırları: Psikanalitik Film Kuramı", Kültür ve İletişim, 12(1), s. 9-38.

Baker, Ulus, (2014). Kanaatlerden İmajlara: Duygular Sosyolojisine Doğru, İstanbul: Birikim Yayınları.

Coetzee, John Maxwell, (1990). Düşman, İstanbul: Adam Yayıncılık.

Derrida, Jacques, (1991). Of Spirit: Heidegger and the Question, Chicago: University of Chicago Press.

Derrida, Jacques, (2017). Dissemination, Chicago: University of Chicago Press.

Fink, Bruce, (1995). "The Real Cause of Repetition", Reading Seminar XI, New York: State University of New York Press.

Fink, Bruce, (1995). The Lacanian Subject: Between Language and Jouissance, New Jersey: Princeton University Press.

Foucault, Michel, (2005). Özne ve İktidar, İstanbul: Ayrıntı Yayınları.

Foucault, Michel, (2007). Cinselliğin Tarihi. İstanbul: Ayrıntı Yayınları.

Hobsbawm, Eric, (2012). “The Invention of Tradition”, Cambridge: Cambridge University Press.

Jaanus, Maire, (1995). "The Demontage of the Drive", Reading Seminar XI, New York: State University of New York Press.

Lacan, Jacques, (1990). Television: A Challenge to the Psychoanalytic Establishment, New York: W. W. Norton.

Lacan, Jacques, (1999). On Feminine Sexuality, the Limits of Love and Knowledge (Encore), Seminar XX, New York: W.W. Norton,

Lacan, Jacques, (2005). "Çalınan Mektup Üzerine Seminer", Çalınan Poe: Lacan ve Derrida, İstanbul: Birey Yayıncılık.

Lacan, Jacques, (2005). Ecrits, New York: W. W. Norton.

Lacan, Jacques, (2014). Psikanalizin Dört Temel Kavramı, Seminer 11. Kitap, İstanbul: Metis Yayınları.

Lemaire,Anika, (1977). Lacan, London: Routledge.

Marx, Karl, (2014). Kömünist Manifesto, İstanbul: Sis Yayınc1lık.

Roudinesco, Elisabeth, (2012). Her şeye ve Herkese Karşı Lacan, İstanbul: Metis Yayınları.

Spivak, Gayatri Chakravorty, (1999). İşe Koyulmak, Ulusötesi Kültürel Çalışmalar, Eleştirel Bakış, Ankara: Dost Kitabevi Yayınları. 
Spivak, Gayatri Chakravorty, (2010). "Can the Subaltern Speak?", Can the Subaltern Speak?: Reflections on the History of an Idea, New York: Columbia University Press.

Tyrer, Ben, (2017). "This tongue is not my own: Dogtooth, Phobia and the Paternal Metaphor", Contemporary Greek Film Cultures from 1990 to the Present, Oxford: Peter Lang, s. 101-129.

Wittgenstein, Ludwig, (2006). Tractatus Logico-Philosophicus, İstanbul: Metis Yayınlar1.

Zizek, Slavoj, (2003). Gıdıklanan Özne: Politik Ontolojinin Yok Merkezi, İstanbul: Epos Yayınları.

Zizek, Slavoj, (2005). Yamuk Bakmak: Popüler Kültürden JacquesLacan'a Giriş, İstanbul: Metis Yayıncilık.

Zizek, Slavoj, (2006). Kırılgan Temas, İstanbul: Metis Yayınları. 